\title{
Nutrient Availability in Rangeland Soils: Influence of Prescribed Burning, Herbaceous Vegetation Removal, Overseeding with Bromus tectorum, Season, and Elevation
}

\author{
R. R. Blank, ${ }^{1}$ J. Chambers, ${ }^{2}$ B. Roundy, ${ }^{3}$ and A. Whittaker ${ }^{4}$
}

Authors are ${ }^{1}$ Soil Scientist, USDA-Agricultural Research Service, Exotic and Invasive Weed Research Unit, 920 Valley Road, Reno, NV 89512; ${ }^{2}$ Plant Ecologist, USDA-Forest Service, 920 Valley Road, Reno, NV 89512; ${ }^{3}$ Professor of Range Science, Brigham Young University, Provo, UT 84602; and ${ }^{4}$ Wildlife Biologist, Division of Wildlife Resources, 494 W 100 S, Ephraim, UT 84627.

\begin{abstract}
Soil nutrient availability influences plant invasions. Resin capsules were used to examine soil nutrient bioavailability along 2 sagebrush-grassland elevation transects in the east Tintic Range (Utah) and Shoshone Range (Nevada). In the fall of 2001, treatments were applied to 3 replicate plots at each site, which included prescribed burning, herbaceous vegetation removal, and controls. Cheatgrass (Bromus tectorum L.) was overseeded in small subplots within each treatment. Following treatments in each plot, resin capsules were installed at $15-\mathrm{cm}$ depth in a shrub interspace and a B. tectorum-overseeded area. Nutrient availability was integrated during late fall to spring and spring to late fall for 2 years. Herbaceous vegetation removal increased availability of nitrate (Nevada and Utah) and $\mathrm{Ca}$ and $\mathrm{Mg}$ (Nevada only) but only during the second sampling period (growing season). Availability of K and ortho-P (Nevada and Utah) and nitrate (Nevada only) was greater on prescribed burned plots. For Utah, availability of ortho-P, K, Ca, Mg, and Fe generally increased with increasing elevation. Availability of $\mathrm{Ca}, \mathrm{Mg}, \mathrm{K}$, and Fe was greatest during late fall to spring integration periods for Nevada. Overseeding with B. tectorum interacted with the burn treatment to influence availability of $\mathrm{Ca}, \mathrm{Mg}$, and Fe (Nevada sites only). Patterns of nutrient availability can be explained by a combination of decreased root uptake in relation to mineralization, differences in soil water content with season and elevation, and nutrient release from vegetation and soil as a consequence of prescribed burning. Herbaceous vegetation removal and burning can raise nitrate availability and increase risk of invasion by nitrophilic species such as $B$. tectorum. Nutrient availability can be out of phase with plant growth; plants capable of taking up nutrients during cold periods may have a competitive advantage. Resin capsules have utility in quantifying the effects of treatments on the availability of many soil nutrients.
\end{abstract}

\section{Resumen}

La disponibilidad de nutrientes en el suelo influye en las invasiones de plantas. Se usaron capsulas de resina para examinar la biodisponibilidad de los nutrientes del suelo a lo largo de 2 transectos de elevación en comunidades de pastizal- "Sagebrush" al este de los campos Tintic (Utah) y Shoshone (Nevada). En el otoño de 2001 se aplicaron los tratamientos en 3 parcelas repetidas en cada sitio, los cuales fueron: quema prescrita, remoción de la vegetación herbácea y el control. Se sobresembró Bromus tectorum L. en pequeñas subparcelas dentro de cada tratamiento. Posterior a la aplicación de tratamientos, en cada parcela se instalaron las capsulas de resina a $15 \mathrm{~cm}$ de profundidad en un espacio entre arbustos y en una área sembradas con $B$. tectorum L. La disponibilidad de nutrientes fue integrada de fines de otoño a primavera y de primavera a fines de otoño durante dos años. La remoción de vegetación herbácea aumentó la disponibilidad de nitratos (en ambos estados), Ca y Mg (solo en Nevada), pero solo durante el segundo periodo de muestreo (estación de crecimiento). La disponibilidad de $\mathrm{K}$ y ortofosfatos (en ambos estados) y nitratos (en Nevada) fueron mayores en las parcelas con quema prescrita. En Utah, la disponibilidad de ortofosfatos, K, Ca, Mg y Fe generalmente se incrementaron al aumentar la elevación. En Nevada, la disponibilidad de Ca, Mg, K y Fe fue mayor en los periodos de integración de fines de otoño a primavera. La sobresiembra de B. tectorum interactuó con el tratamiento de quema para influenciar la disponibilidad de $\mathrm{Ca}, \mathrm{Mg}$, y Fe (solo en los sitios de Nevada). Los patrones de disponibilidad de nutrientes pueden ser explicados por una combinación de una disminución de la absorción por las raíces en relación a la mineralización, diferencias en el contenido de agua del suelo con la época y elevación y la libración de nutrientes de la vegetación y suelo como consecuencia de la quema prescrita. La remoción de la vegetación herbácea y la quema pueden elevar la disponibilidad de nitratos e incrementar el riesgo de invasión por especies nitrofílicas como el B. tectorum. La disponibilidad de nutrientes puede estar desfasada del crecimiento vegetal; plantas capaces de tomar nutrientes durante los periodos fríos pueden tener una ventaja competitiva. Las capsulas de resina tienen utilidad para evaluar la disponibilidad de un arreglo de nutrientes del suelo.

Key Words: nutrient availability, resin capsules, rangeland soils

\section{INTRODUCTION}

Correspondence: Dr Robert Blank, USDA-Agricultural Research Service, Exotic and Invasive Weed Research Unit, 920 Valley Road, Reno, NV 89512. Email: blank@unr.nevada.edu

Manuscript received 1 September 2006; manuscript accepted 19 August 2007.
Soil nutrient availability (bioavailability) is a principal factor constraining vegetative growth and organizing competitive interactions among species (Tilman 1982; Goldberg 1990; 
Grover 1997). Availability of nutrients, such as nitrogen and phosphorus, influences whether ecosystems can resist, or are prone to, invasion by exotic plant species (Burke and Grime 1996; Herron et al. 2001). There are no universally accepted protocols or ideal methodologies to unambiguously gauge soil nutrient availability. Chemical extracts have proven valuable as indicators of bioavailability, but they provide only a one-time measure of nutrient availability. The utility of extracts in natural ecosystems has been hindered by poor relationships between measured values and plant growth because of inherent variability among plant species in growth rates, seasonal timing of growth, nutrient uptake kinetics, phenotypic plasticity, and the mineralization potential of organic matter (Chapin 1980; Grime et al. 1986; Ågren and Bosatta 1996; Janssen 1996). Phosphorus and nitrogen have proven especially difficult to correlate extractable pools with true bioavailability (Saggar et al. 1992). To overcome limitations of chemical extracts, researchers use anion and cation resin exchangers to integrate soil nutrient availability over time (Binkley et al. 1986). Resin exchangers also have limitations (Sherrod et al. 2003; Johnson et al. 2005) but have been shown to relate to nutrient release kinetics and bioavailability of particular nutrients (van Raij et al. 1986; Searle 1988; Abrams and Jarrell 1992; Yang and Skogley 1992).

Soil nutrient availability is often patchy and both spatially and temporally variable (Davy and Taylor 1974; Gross et al. 1995; Farley and Fitter 1999). Pulses of nutrient availability can be opportunistically exploited by plants (Cui and Caldwell 1997; Farley and Fitter 1999), are robust predictors of ecosystem invasibility, and can have lasting effects on competition intensity (Davis et al. 2000; Davis and Pelson 2001). Fast-growing exotic species, such as cheatgrass (Bromus tectorum L.), can take advantage of nutrient pulses and co-opt mineral nutrients and water faster than competing species (Monaco et al. 2003). Availability of soil nutrients in sagebrush-grass ecosystems is spatially and temporally variable (Doescher et al. 1984; Burke 1989). Does this fact imply that these ecosystems are inherently at risk of invasion? It is impossible to draw any conclusions because we are unaware of any literature that defines a threshold level of nutrient availability at which an ecosystem becomes vulnerable to invasion. Disturbances from biomass removal, vegetation mortality, physical transformation of the soil, or a combination of these factors can cause nutrient pulses to the extent that community structure is altered (Picket and White 1985; Crawley 1987; Bazzaz 1996).

Fire can create a pulse of nutrient availability, which, combined with loss of vegetation, can open an invasion window. The magnitude and direction of change depends on fuel loads, fire intensity, the nature of the surface-soil mineral fraction, soil organic matter content, vegetation type, and antecedent soil moisture levels (DeBano and Conrad 1978; Pyne et al. 1996; Neary et al. 1999). Low-temperature fires $\left(<450^{\circ} \mathrm{C}\right)$, typical in sagebrush grasslands (Wright and Bailey 2004), generally increase availability of N, S, K, and other base cations (Blank et al. 1994, 2003). Postfire sorption and precipitation reactions and leaching can significantly affect soil nutrient availability (Dudley and Lajtha 1994), and the longevity of elevated nutrient availability can range from weeks to years (Hobbs and Schimel 1983; Neary et al. 1999).
Herbivory (vegetation removal) can influence nutrient availability directly through plant mortality and soil decomposition processes. Herbivory can also have indirect effects on nutrients through changes in species composition and, consequently, rooting depths and uptake patterns. In sagebrush ecosystems, depletion of the perennial herbaceous component has typically favored deeper-rooted shrubs (Jackson et al. 1996). Switching from herbaceous-dominated to shrub-dominated ecosystems can alter both the timing and amount of available water and nutrients. Both direct and indirect effects of herbivory can produce pulses of nutrient availability and increase susceptibility to invasion. Similar mechanisms could also operate with vegetation removal and death of plants upon herbicide treatment (Guo et al. 2004).

Invasion by exotic plant species can alter nutrient cycles (see Ehrenfeld 2003 for review), and many invasive plants are capable of engineering the ecosystem to facilitate their invasiveness (Vitousek et al. 1987). Invasion by cheatgrass disrupts food webs, alters soil $\mathrm{N}$ dynamics, lowers species diversity, and decreases fungal populations (Belnap and Phillips 2001; Evans et al. 2001). Particular environments are resistant to invasion by exotic plant species (Burke and Grime 1996; Stohlgren et al. 1999). In sagebrush steppes, high elevation (colder and greater precipitation) areas occupied by robust communities of bunchgrass, such as Festuca idahoensis Elmer (Idaho fescue) and Pseudoroegneria spicata (Pursh) A. Löve (bluebunch wheatgrass) are more resistant to invasion by $B$. tectorum than lower elevation areas occupied by sparse bunchgrass communities of Poa spp., Elymus elymoides (Raf.) Swezey (squirreltail), and Stipa spp. This resistance may be due to tighter coupling of soil nutrient availability with plant uptake, which keeps nutrient availability below a threshold level for plant invasion. Greater soil development and precipitation of high-elevation bunchgrass communities may pose an invasion risk if there is a decoupling of nutrient uptake with mineralization.

In temperate environments, nutrient availability varies seasonally. In general, soil nutrients are most available in the spring and early summer when temperature and moisture are favorable, and mineralization is rapid. Cold winter temperatures limit microbial-mitigated mineralization and one would expect availability to decrease; however, considerable soil mineralization and nutrient uptake by microbes can occur beneath an insulating snowpack (Brooks et al. 1996; Grogan and Jonasson 2003). In the Great Basin, most precipitation occurs in winter and spring and is out of phase with plant growth. Winter precipitation combined with fairly common periods of warm weather may stimulate pulses of microbial activity and concomitant increases in mineralization. Thus, in the sagebrush steppe, pulses of nutrient availability may occur at any time of the year. Plants capable of using these pulses of nutrient availability may have a competitive advantage. Unfortunately, there are very limited data on the ability of wild plants to exploit nutrients during the cold winter season. Root growth can occur from $5^{\circ}$ to $40^{\circ} \mathrm{C}$, but there is marked variation among species-many species uptake nutrients in the $5^{\circ}-10^{\circ} \mathrm{C}$ range (Bowen 1991).

In-situ ion-exchange techniques are now frequently used to monitor soil chemistry for comparative purposes (Drohan et al. 2005). This study was initiated to gauge soil nutrient bioavailability of $\mathrm{NO}_{3}^{-}$, ortho-P, $\mathrm{K}^{+}, \mathrm{Ca}^{+2}, \mathrm{Mg}^{+2}, \mathrm{Fe}, \mathrm{Mn}$, and 
Table 1. Site and soils information for Shoshone Range of Nevada.

\begin{tabular}{|c|c|c|c|c|c|c|c|c|c|}
\hline \multirow[b]{2}{*}{ Site } & \multirow[b]{2}{*}{ Vegetation type } & \multirow[b]{2}{*}{ Elevation (m) } & \multirow[b]{2}{*}{ Soil classification } & \multirow[b]{2}{*}{ Parent materials } & \multicolumn{5}{|c|}{ A horizon } \\
\hline & & & & & $\%$ Coarse & Texture & $\% \mathrm{OC}^{1}$ & $\% \mathrm{~N}$ & $\mathrm{pH}$ \\
\hline Crested & Agropyron cristatum & 2060 & $\begin{array}{l}\text { loamy-skeletal, } \\
\text { mesic, Xereptic } \\
\text { Haplodurids }\end{array}$ & $\begin{array}{l}\text { welded and nonwelded, } \\
\text { Rhyolitic ash flow tuffs }\end{array}$ & 12 & Sandy loam & 1.13 & 0.14 & 5.86 \\
\hline Lower & $\begin{array}{l}\text { Artemisia tridentata, } \\
\text { subsp. wyomingensis }\end{array}$ & 1963 & $\begin{array}{l}\text { loamy-skeletal, } \\
\text { mesic, Xeric } \\
\text { Haplocambids }\end{array}$ & same & 31 & Sandy loam & 0.85 & 0.145 & 5.02 \\
\hline Middle & $\begin{array}{c}\text { Artemisia tridentata, } \\
\text { subsp. vaseyana }\end{array}$ & 2188 & $\begin{array}{l}\text { loamy-skeletal, mesic, } \\
\text { Typic Haploxerolls }\end{array}$ & same & 62 & Sandy loam & 2.26 & 0.127 & 5.16 \\
\hline Upper & $\begin{array}{c}\text { Artemisia tridentata, } \\
\text { subsp. vaseyana }\end{array}$ & 2377 & $\begin{array}{l}\text { fine-loamy and } \\
\text { loamy-skeletal, frigid } \\
\text { Typic Haploxerolls }\end{array}$ & same & 34 & Loam & 1.27 & 0.151 & 4.82 \\
\hline
\end{tabular}

${ }^{1} \mathrm{OC}$ indicates organic carbon.

$\mathrm{Na}^{+}$in sagebrush-grass ecosystems using mixed-anion and cation resin capsules. We examined the response of soil nutrient bioavailability to herbaceous vegetation removal, prescribed fire, and seeding. Our working null hypotheses were the following:

1) herbaceous vegetation removal does not affect soil nutrient availability

2) prescribed burning does not affect soil nutrient availability

3) seeding of $B$. tectorum does not affect soil nutrient availability

4) soil nutrient availability is unaffected by season

5) soil nutrient availability is unaffected by elevationmoisture gradients

\section{MATERIALS AND METHODS}

Hypothesis testing was facilitated by choosing representative elevation-vegetation gradients in the east Tintic Range of Utah and the Shoshone Range of central Nevada. Four sites were chosen in Nevada (Table 1) and 5 sites in Utah (Table 2). Sites were fenced to exclude grazing. In 2001, circular plots, $3.0 \mathrm{~m}$ in diameter, were inscribed within sites to encompass a representative shrub-interspace environment. Treatments randomly applied were control (no herbaceous vegetation removal or burning), prescribed burning, and herbaceous vegetation removal. At each site, the treatment matrix (3 replicates) was as follows: 1) control (no vegetation removal and unburned), 2) one-half herbaceous vegetation removal (Nevada only), 3) total herbaceous vegetation removal (Nevada and Utah), 4) no vegetation removal+prescribed fire, 5) one-half herbaceous vegetation removal + prescribed fire (Nevada only), and 6) total herbaceous vegetation removal + prescribed fire. These treatments amounted to a total of 18 plots per site in Nevada and 12 in Utah. On all plots, a subplot of $0.75 \times 0.75 \mathrm{~m}$ in a shrubinterspace position was overseeded with the weight-equivalent of 648 filled seeds of B. tectorum. Seeds were sown in 2001 in mid-October for Nevada and mid-November for Utah. Herbaceous vegetation removal was accomplished by spraying with glyphosate; one-half removal involved spraying every other perennial plant, and total removal involved spraying all understory vegetation. On the intact and one-half-removal plots, existing B. tectorum was removed by hand. Prescribed burning used burn barrels with $4.5 \mathrm{~kg}$ of clean, dry straw spread evenly over plots to facilitate complete burn coverage

Table 2. Site and soil information for the east Tintic Range of Utah.

\begin{tabular}{|c|c|c|c|c|c|c|c|c|}
\hline \multirow[b]{2}{*}{ Site } & \multirow[b]{2}{*}{ Vegetation type } & \multirow[b]{2}{*}{ Elevation (m) } & \multirow[b]{2}{*}{ Soil classification } & \multirow[b]{2}{*}{ Parent materials } & \multicolumn{4}{|c|}{ A horizon } \\
\hline & & & & & $\%$ Coarse & Texture & $\% O C^{1}$ & $\% \mathrm{~N}$ \\
\hline Elel & Elymus elymoides & 1597 & $\begin{array}{l}\text { fine-loamy to loamy-skeletal, } \\
\text { mesic, Xeric Haplocalcids }\end{array}$ & $\begin{array}{l}\text { basic igneous rocks, } \\
\text { limestone, quartzite }\end{array}$ & 20 & Sandy loam & 1.06 & 0.12 \\
\hline Crested & Agropyron cristatum & 1627 & $\begin{array}{l}\text { fine-loamy to loamy-skeletal, } \\
\text { mesic, Xeric Haplocalcids }\end{array}$ & $\begin{array}{l}\text { basic igneous rocks, } \\
\text { limestone, quartzite }\end{array}$ & 2 & Loam & 1.78 & 0.13 \\
\hline Lower & $\begin{array}{l}\text { Artemisia tridentata, } \\
\text { subsp. wyomingensis }\end{array}$ & 1707 & $\begin{array}{l}\text { Ioamy-skeletal, carbonatic, } \\
\text { mesic, shallow, } \\
\text { Petrocalcic Palexerolls }\end{array}$ & limestone, sandstone & 34 & Sandy loam & 1.79 & 0.15 \\
\hline Middle & $\begin{array}{l}\text { Artemisia tridentata, } \\
\text { subsp. vaseyana }\end{array}$ & 2085 & $\begin{array}{l}\text { Ioamy-skeletal, carbonatic, } \\
\text { mesic, Lithic Calcixerolls }\end{array}$ & limestone & 34 & Loam & 2.57 & 0.21 \\
\hline Upper & $\begin{array}{l}\text { Artemisia tridentata, } \\
\text { subsp. vaseyana }\end{array}$ & 2274 & $\begin{array}{l}\text { Ioamy-skeletal, carbonatic, } \\
\text { mesic, frigid, Lithic Calcixerolls }\end{array}$ & limestone, shale & 42 & Loam & 3.97 & 0.35 \\
\hline
\end{tabular}

${ }^{1} \mathrm{OC}$ indicates organic carbon. 
(Korfmacher et al. 2002). Burning was done in early October 2001 for Nevada and in early November 2001 for Utah.

Following treatment applications, high-capacity anion and cation resin capsules (Unibest Inc, Bozeman, MT) were placed in plots at a depth of $15 \mathrm{~cm}$ in 2 shrub-interspace locations. One capsule was placed in the periphery of the plot in an unvegetated area to mimic nutrient availability unaffected by root uptake. However, we cannot discount that roots may have moved into that area during the experiment. The other resin capsule was placed in the B. tectorum overseeded subplot. In the first resin-sampling period, capsules were placed in the center of the subplot, but in following periods, we tried to place capsules directly beneath an establishing B. tectorum plant. Resin capsules were left in the soil to integrate nutrient availability during the following 4 periods: Nevada $=$ from 2 September 2001 to 22 May 2002, 22 May 2002 to 2 November 2002, 2 November 2002 to 19 May 2003, 19 May 2003 to 24 October 2003; Utah $=$ from 16 November 2001 to 20 May 2002, 20 May 2002 to 7 November 2002, 7 November 2002 to 21 July 2003, 21 July 2003 to 1 December 2003. Because of early snowfall, the upper Utah site resin capsules could not be collected for the last integration period.

Resin capsules were returned to the laboratory and rinsed extensively with deionized water to remove adhering and inculcated soil particles. Capsules were then placed in clean 50$\mathrm{mL}$ polypropylene tubes and dried. Adsorbed solutes were released by adding $40 \mathrm{~mL}$ of $1 \mathrm{~N} \mathrm{HCl}$ and shaking for 1 hour on a reciprocating shaker. After shaking, tubes were centrifuged, decanted into clean $50-\mathrm{mL}$ polypropylene tubes, and stored until analyzed. For each analysis time, 2 to 4 blanks (fresh resin capsules) were made up similarly. Nitrate, $\mathrm{NH}_{4}^{+}$, and ortho-P were quantified using the Lachat flow-injection system (Lachat Corp, Mequon, WI). Resin-extractable $\mathrm{NH}_{4}^{+}$ was quantified with the Kjeldahl-digestion module; however, because field values were similar to blanks, we chose not to analyze these data statistically. Ortho-P was quantified using a vanomolybdate module suitable for high-acid matrices. All other sorbed nutrients were measured by atomic-adsorption spectroscopy ( $\mathrm{Fe}, \mathrm{Mn}, \mathrm{Zn}, \mathrm{Cu}, \mathrm{Ca}, \mathrm{Mg}$ ) or atomic-emission spectroscopy $(\mathrm{K}$ and $\mathrm{Na}$ ). All standards were made up in $1 \mathrm{~N}$ $\mathrm{HCl}$ using certified standards. Data were converted to micromoles sorbed per day.

We statistically analyzed states separately because we expected nutrient availability to differ based on soil and geologic variance. Measured attributes were converted mathematically to assure normality, most often with a log transformation. The experimental design is a randomized block with 5 sites (S), 5 in Utah and 4 in Nevada with 2 factorial treatments (burning $[\mathrm{B}]$, herbaceous vegetation removal [HVR]). The overseeding (OS) treatment was considered a split plot within treatments. Random effects were $S, B \times H V R \times S$, $\mathrm{S} \times \mathrm{B} \times \mathrm{HVR} \times \mathrm{OS}$, and $\mathrm{T} \times \mathrm{S} \times \mathrm{B} \times \mathrm{HVR} \times \mathrm{OS}$. Time of measurement $(T)$ was included as an independent effect. Site (elevation) was analyzed as a random variable, and differences among sites were determined using contrasts between predictable functions (Stroup 1989; SAS 2001, using best linear unbiased predictor [BLUP]). We used PROC MIXED (SAS 2001) and Tukey's honest significant difference to separate means. Significance was judged at the $<0.10$ level.

\section{RESULTS AND DISCUSSION}

\section{Herbaceous Vegetation Removal and Nutrient Availability}

Soil availability of $\mathrm{NO}_{3}^{-}$was significantly affected by herbaceous vegetation removal in both states (Tables 3 and 4; Fig. 1). For Nevada, total herbaceous removal resulted in a trend toward higher $\mathrm{NO}_{3}^{-}$availability for all integration periods but was significant only for the second integration period. Nitrate availability for Utah sites was affected only by the main effect of herbaceous vegetation removal. Calcium and $\mathrm{Mg}^{+2}$ availability was influenced by a significant interaction between herbaceous vegetation removal and resin integration period. Similar to $\mathrm{NO}_{3}^{-}$, total herbaceous removal accounted for higher $\mathrm{Ca}^{+2}$ and $\mathrm{Mg}^{+2}$ availability during the second integration period. Herbaceous vegetation removal did not affect availability of $\mathrm{Ca}^{+2}$ or $\mathrm{Mg}^{+2}$ for the Utah sites. Because herbaceous vegetation removal affected $\mathrm{NO}_{3}^{-}$availability, we reject null hypothesis 1 .

Vegetation removal can elevate nutrient availability (Davis and Pelsor 2001). In this study, total vegetation removal increased time of water availability at depths of 18-20 and 28$30 \mathrm{~cm}$ compared with control treatment (Whittaker 2006), which could enhance mineralization rates. Cell lysing and mineralization of dying herbaceous roots can potentially add to the available pools of all nutrients. Vegetation removal can elevate soil temperatures and correspondingly increase mineralization rates (Gurlevik et al. 2004). In certain ecosystems, elevated $\mathrm{N}$ following herbaceous vegetation removal is speculated to be a consequence of decreased phytotoxicity and a corresponding increase in microbial-mediated mineralization (Lodhil 1981). Available $\mathrm{N}$ can also increase once vegetation is removed because a major sink for nutrient uptake no longer exists; mineralization then exceeds root uptake. Soil microbes are capable of using these available nutrients and perhaps forestalling increases in nutrient availability. We suspect, however, decreased C flow from dead herbaceous roots will, at some point, cause microbial activity to wane and increase availability of $\mathrm{N}$. This scenario may partially explain the delay for the Nevada sites, where herbaceous vegetation removal increased $\mathrm{N}$ availability (Fig. 1). Another mechanism that could influence the effect of herbaceous vegetation removal on nutrient availability is incursion of shrub roots and roots from outside the plots into the soil of the dead vegetation. Roots are capable of rapid growth when seeking out fertile microsites (Larigauderie and Richards 1994). Root incursion may explain why elevated $\mathrm{N}$ availability with total herbaceous vegetation removal was short lived on the Nevada sites (Fig. 1). The lack of an interaction of $\mathrm{N}$ availability with season for the Utah site is perplexing. Perhaps the calcareous reaction of the Utah soils influences seasonal aspects of herbaceous vegetation removal. Nutrient deficiencies often characteristic of calcareous soil, especially of Fe, often reduce root growth (White 1990). In summary, herbaceous vegetation removal can cause a pulse of elevated $\mathrm{N}$ availability resulting in greater risk of invasion by nitrophilic species, such as $B$. tectorum.

For the Nevada sites, the pattern of $\mathrm{Ca}^{+2}$ and $\mathrm{Mg}^{+2}$ availability, as influenced by herbaceous vegetation removal, mimicked that of $\mathrm{N}$, which suggests a similar underlying mechanism. Availability of $\mathrm{Ca}^{+2}$ and $\mathrm{Mg}^{+2}$, however, is 
Table 3. ANOVA probability values for 8 essential elements on the Nevada research area (bold fonts denote significance, $P<0.10$ ).

\begin{tabular}{|c|c|c|c|c|c|c|c|c|}
\hline Effect & Ortho-P & $\mathrm{NO}_{3}^{-}$ & K & $\mathrm{Ca}$ & $\mathrm{Mg}$ & $\mathrm{Fe}$ & $\mathrm{Mn}$ & $\mathrm{Na}$ \\
\hline Time & 0.0004 & 0.1787 & 0.0143 & 0.0017 & 0.0039 & 0.3766 & 0.0105 & $<0.0001$ \\
\hline Burn & 0.0687 & 0.0688 & 0.0047 & 0.8849 & 0.3887 & 0.448 & 0.8355 & 0.0039 \\
\hline Time $\times$ burn & 0.7628 & 0.3759 & 0.2382 & 0.7373 & 0.0973 & 0.8973 & 0.5489 & 0.0223 \\
\hline Seed & 0.3153 & 0.7796 & 0.2435 & 0.5125 & 0.5048 & 0.1602 & 0.2484 & 0.1509 \\
\hline Time $\times$ seed & 0.9969 & 0.4752 & 0.4036 & 0.2264 & 0.2296 & 0.6113 & 0.351 & 0.844 \\
\hline Burn $\times$ seed & 0.9326 & 0.6888 & 0.244 & 0.0184 & 0.0215 & 0.0644 & 0.1012 & 0.2242 \\
\hline Time $\times$ burn $\times$ seed & 0.2748 & 0.159 & 0.9805 & 0.8641 & 0.9183 & 0.9616 & 0.7755 & 0.7068 \\
\hline Removal & 0.4707 & $<0.0001$ & 0.5211 & 0.2161 & 0.3322 & 0.2138 & 0.7244 & 0.1622 \\
\hline Time $\times$ removal & 0.7888 & 0.0022 & 0.3623 & 0.0374 & 0.0494 & 0.2742 & 0.1504 & 0.2836 \\
\hline Burn $\times$ removal & 0.6403 & 0.5606 & 0.8124 & 0.3541 & 0.2644 & 0.966 & 0.9475 & 0.6997 \\
\hline Time $\times$ burn $\times$ removal & 0.9648 & 0.3729 & 0.4992 & 0.6835 & 0.5517 & 0.076 & 0.3544 & 0.9432 \\
\hline Seed $\times$ removal & 0.2784 & 0.5656 & 0.4592 & 0.3848 & 0.533 & 0.6756 & 0.6608 & 0.9072 \\
\hline Time $\times$ seed $\times$ removal & 0.6185 & 0.6879 & 0.5774 & 0.7052 & 0.5561 & 0.1822 & 0.7749 & 0.2428 \\
\hline Burn $\times$ seed $\times$ removal & 0.3128 & 0.2837 & 0.6622 & 0.6065 & 0.8214 & 0.883 & 0.9776 & 0.5903 \\
\hline Time $\times$ burn $\times$ seed $\times$ removal & 0.8788 & 0.5702 & 0.9654 & 0.5108 & 0.9443 & 0.7636 & 0.7328 & 0.8723 \\
\hline
\end{tabular}

generally controlled by exchange reactions with the soil clay fraction (Tisdale and Nelson 1975) and is not likely to be affected by soil mineralization processes. Plots with total herbaceous vegetation removal had longer periods of soil water availability than did the control treatments (Whittaker 2006). As transport of $\mathrm{Ca}^{+2}$ and $\mathrm{Mg}^{+2}$ through the soil is diffusion limited, higher soil water contents would lessen tortuosity and increase their mobility (Barber 2001) and availability. We believe that because the Utah soils contain free $\mathrm{CaCO}_{3}, \mathrm{Ca}^{+2}$ and $\mathrm{Mg}^{+2}$ availability are relatively unaffected by herbaceous vegetation removal. Potential benefits to plants of elevated $\mathrm{Ca}^{+2}$ and $\mathrm{Mg}^{+2}$ availability in these ecosystems are likely minimal given the relatively high background levels.

\section{Prescribed Fire and Nutrient Availability}

Relative to unburned plots, prescribed burning in the fall of 2001 led to significantly higher resin availability of $\mathrm{NO}_{3}^{-}$ (Nevada only) and of $\mathrm{K}^{+}$and ortho-P (Utah and Nevada; Fig. 2; Tables 3 and 4). Resin-available $\mathrm{Na}^{+}$was also increased because of prescribed burning (Fig. 2; Tables 3 and 4). For the Nevada sites, $\mathrm{Na}^{+}$was significantly greater on burned plots only during the overwinter sampling periods. For the Utah sites, $\mathrm{Na}^{+}$availability was much higher on the burned plots during the overwinter season immediately after the prescribed burns and was only slightly elevated, but significant, relative to the unburned plots during the following 3 sampling periods. Because prescribed burning affected availabilities of $\mathrm{NO}_{3}^{-}, \mathrm{K}^{+}$, and $\mathrm{Na}^{+}$, we reject null hypothesis 2 .

Vegetation burning often increases the availability of many soil nutrients, but the increase is predicated on complex relationships among soil type, vegetation type, fuel load, and climatic conditions before and during the fire (Wright and Bailey 2004). In a muffle-furnace study, using several soil-litter types typical of the sagebrush steppes, large increases in watersoluble $\mathrm{K}^{+}$were noted when the soil-litter was heated to above $250^{\circ} \mathrm{C}$ (Blank et al. 1994). In this study, the large increases in $\mathrm{K}^{+}$availability following prescribed burning cannot be due to heat-induced release from the micaceous interlayers because the

Table 4. ANOVA probability values for 8 essential elements on the Utah research area (bold fonts denote significance, $P<0.10$ ).

\begin{tabular}{|c|c|c|c|c|c|c|c|c|}
\hline Effect & Ortho-P & $\mathrm{NO}_{3}^{-}$ & K & $\mathrm{Ca}$ & $\mathrm{Mg}$ & $\mathrm{Fe}$ & $\mathrm{Mn}$ & $\mathrm{Na}$ \\
\hline Time & $<0.0001$ & 0.9039 & 0.0061 & 0.0085 & 0.0256 & 0.0028 & 0.015 & 0.0037 \\
\hline Burn & 0.0268 & 0.2967 & 0.0929 & 0.8824 & 0.8318 & 0.8106 & 0.2382 & 0.0027 \\
\hline Time $\times$ burn & 0.919 & 0.9587 & 0.9946 & 0.6084 & 0.8035 & 0.7813 & 0.7479 & 0.09 \\
\hline Seed & 0.4103 & 0.1151 & 0.5274 & 0.9078 & 0.7842 & 0.2634 & 0.5259 & 0.8215 \\
\hline Time $\times$ seed & 0.9286 & 0.1533 & 0.4875 & 0.8943 & 0.8641 & 0.3022 & 0.5216 & 0.7115 \\
\hline Burn $\times$ seed & 0.8556 & 0.3723 & 0.8431 & 0.931 & 0.7408 & 0.5859 & 0.347 & 0.3852 \\
\hline Time $\times$ burn $\times$ seed & 0.6812 & 0.7587 & 0.9743 & 0.6692 & 0.5345 & 0.9741 & 0.1649 & 0.9266 \\
\hline Removal & 0.4024 & $<0.0001$ & 0.2438 & 0.9581 & 0.746 & 0.3543 & 0.5281 & 0.4035 \\
\hline Time $\times$ removal & 0.9548 & 0.895 & 0.9437 & 0.2746 & 0.3457 & 0.7846 & 0.1288 & 0.9646 \\
\hline Burn $\times$ removal & 0.5776 & 0.3617 & 0.9643 & 0.7361 & 0.6332 & 0.6597 & 0.5295 & 0.7238 \\
\hline Time $\times$ burn $\times$ removal & 0.4609 & 0.3631 & 0.2515 & 0.6027 & 0.7004 & 0.999 & 0.828 & 0.682 \\
\hline Seed $\times$ removal & 0.9018 & 0.2289 & 0.7214 & 0.4098 & 0.2355 & 0.2044 & 0.2259 & 0.422 \\
\hline Time $\times$ seed $\times$ removal & 0.9712 & 0.784 & 0.9261 & 0.3252 & 0.2283 & 0.4364 & 0.8097 & 0.9742 \\
\hline Burn $\times$ seed $\times$ removal & 0.4141 & 0.5221 & 0.2164 & 0.8659 & 0.806 & 0.635 & 0.8846 & 0.6193 \\
\hline Time $\times$ burn $\times$ seed $\times$ removal & 0.6661 & 0.3059 & 0.8894 & 0.869 & 0.7262 & 0.7717 & 0.44 & 0.36 \\
\hline
\end{tabular}



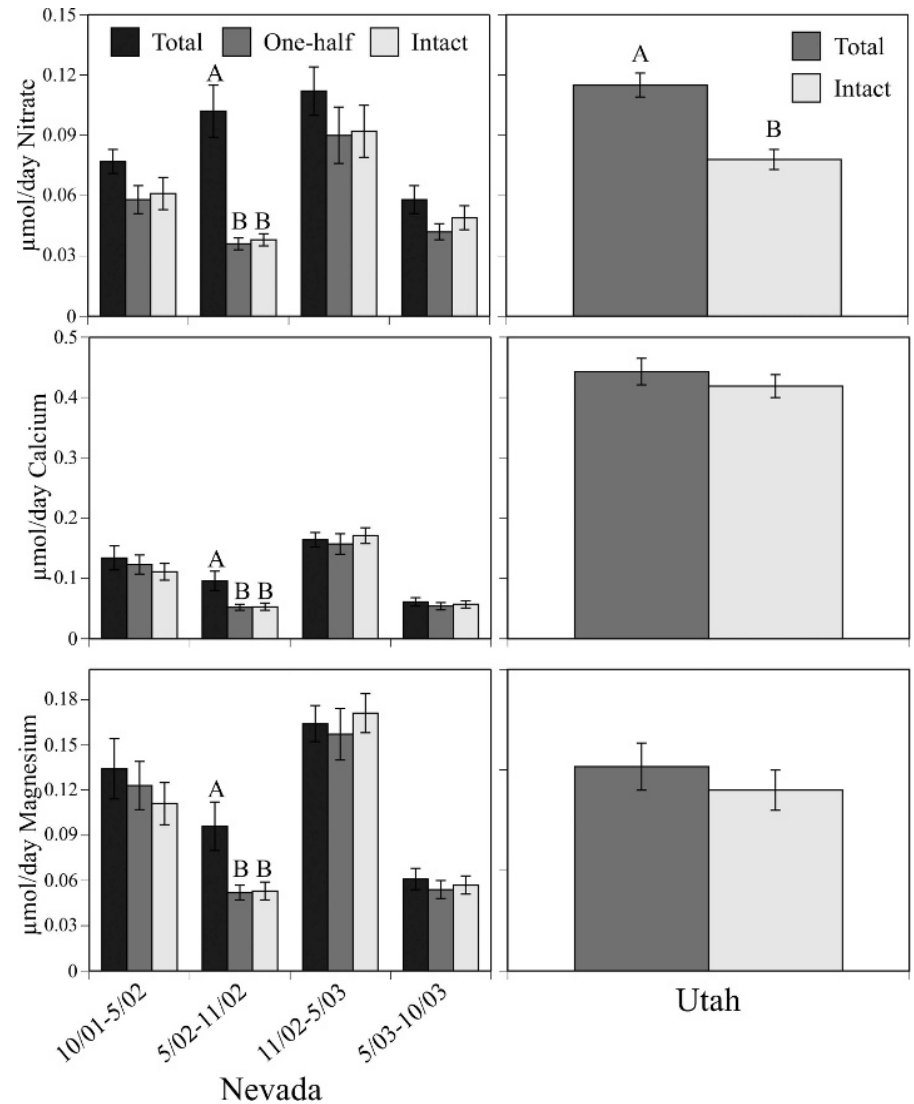

Figure 1. Mean resin availability of nitrate, calcium, and magnesium as affected by herbaceous vegetation removal. For Nevada, data are pooled over site and burn and overseeding treatments; for Utah, data are pooled over site, integration period, and burn and overseeding treatments. Bars are $1 \mathrm{SE}$. For each panel, letters above bars denote significant differences $(P<0.10)$.

parent materials are not plentiful in these minerals. Elevated $\mathrm{K}^{+}$ availability can occur because of release from pyrolyzed vegetation; temperatures of prescribed fires rarely exceed the volatilization point of K (Misra et al. 1993). In addition, elevated temperatures in combination with alteration of soilsolution chemistry can affect exchange reactions; changes in soil-solution levels of $\mathrm{Ca}^{+2}, \mathrm{Mg}^{+2}$, and $\mathrm{Na}^{+}$can affect the availability of $\mathrm{K}^{+}$. The relatively large increase in $\mathrm{K}^{+}$availability following prescribed burning could have large ecological consequences. Potassium is required in large amounts by vegetation, and its increases could benefit plant $\mathrm{K}$ nutrition. Specifically, extra availability of $K$ could enhance cold hardiness, frost tolerance, photosynthetic rates, and water-use efficiency (Marschner 1995).

Vegetation burning generally increases soil $\mathrm{N}$ availability (Raison 1979; Tuininga and Dighton 2004). In the sagebrush steppe, studies have shown that the availability of $\mathrm{N}$ after fire follows a distinct temporal pathway (Blank et al. 1994; Blank et al. 2003; Rau 2005). Immediately following a fire, in the ash bed and the upper soil layer, availability of $\mathrm{NH}_{4}^{+}$can be elevated and that of $\mathrm{NO}_{3}^{-}$is usually reduced. In the months following the fire, availability of $\mathrm{NO}_{3}^{-}$can dramatically increase owing to enhanced mineralization of heat-altered soil organic matter. Postfire elevated $\mathrm{NO}_{3}^{-}$availability can be short lived (less than a year) or can last several years. Given this
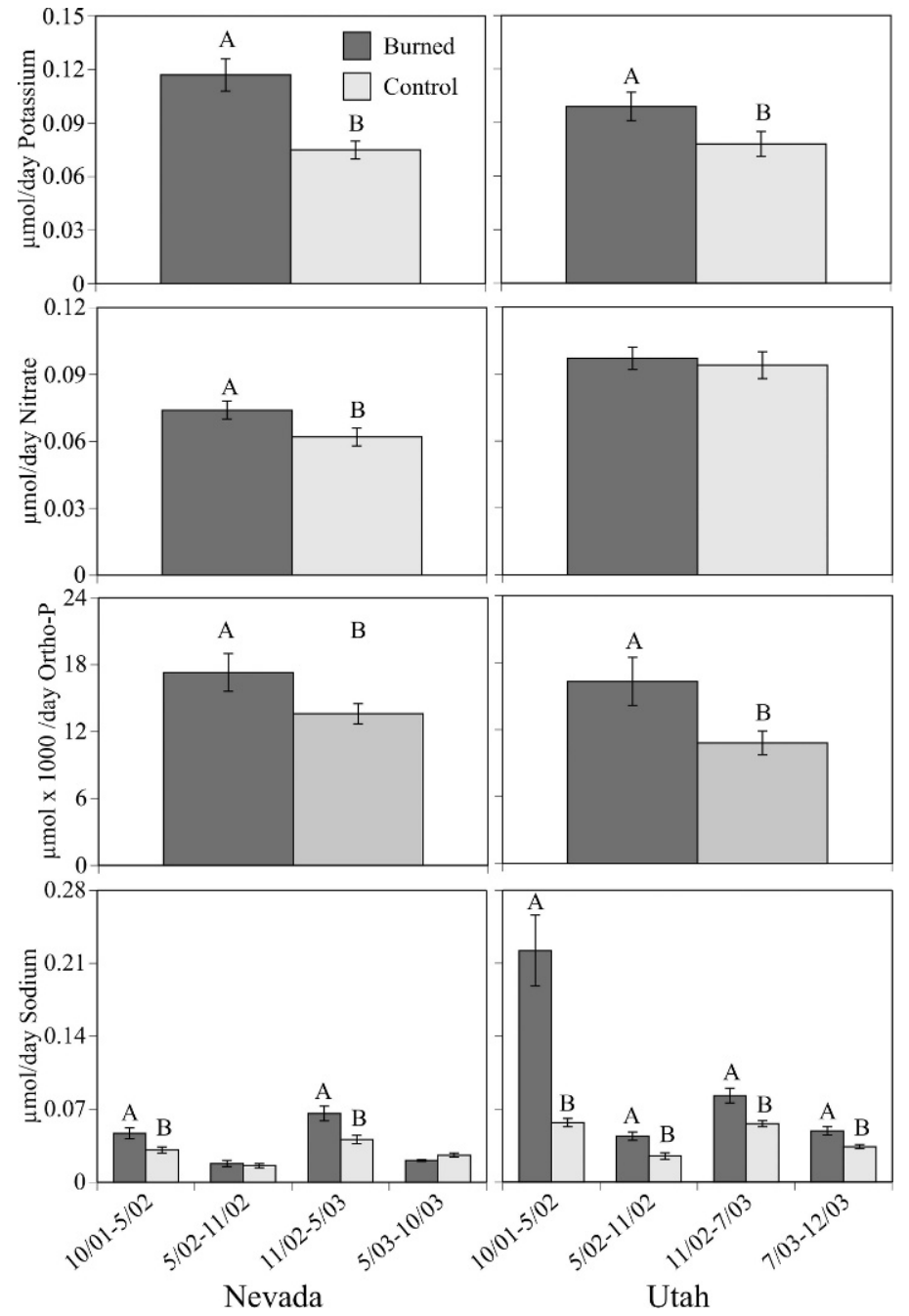

Figure 2. Mean resin availability of potassium, nitrate, ortho-phosphorus (pooled over site, integration period, and herbaceous removal and overseeding treatments), and sodium (pooled over site and herbaceous removal and overseeding treatments) as affected by prescribed burning. Bars are 1 SE. For each panel, letters above bars denote significant differences $(P<0.10)$.

background information, we were surprised that prescribed burning only increased $\mathrm{NO}_{3}^{-}$availability for the Nevada sites. The lack of a prescribed burn effect on $\mathrm{NO}_{3}^{-}$availability for the Utah sites may be a consequence of the presence of $\mathrm{CaCO}_{3}$. Active $\mathrm{CaCO}_{3}$ is known to form stable humo-calcareous complexes resistant to biodegradation (Duchaufour 1977). It is speculative, but perhaps the presence of $\mathrm{CaCO}_{3}$ in the Utah sites protects the soil organic fraction from heat relative to the Nevada sites. For the Nevada sites, resin-available $\mathrm{NO}_{3}^{-}$did not interact with season suggesting that even 2 years after the prescribed burning treatment, availability at the $15-\mathrm{cm}$ depth was enhanced relative to the control. Ancillary research near our study sites in pinyon-juniper woodlands also suggests multiyear enhancement of $\mathrm{N}$ availability because of prescribed burning ( $\mathrm{Rau} 2005$ ). Available $\mathrm{N}$ is generally a limiting nutrient in these ecosystems; therefore, postfire increases in $\mathrm{NO}^{-}$in Nevada sites have potentially large ecological effects. One must be cognizant that beneficial effects of increased $\mathrm{N}$ availability 
for plant growth may be offset by increased risk of exotic plant invasion (Brooks 1999; Davis et al. 2000).

Soil P chemistry is exceedingly complex (McBride 1994); thus, it is not surprising that the availability of $\mathrm{P}$ can increase or decrease depending on the interaction of fire intensity with surface soil characteristics (DeBano et al. 1998; Wright and Bailey 2004). Also, it is difficult to attribute P bioavailability to a particular extractable pool. A postfire increase or decrease in any pool may have little relevance to what is biologically available. However, resin-extractable $\mathrm{P}$ appears to be a robust predictor of that fraction of soil $\mathrm{P}$ that is actually bioavailable (van Raij et al. 1986). Thus, the large increases in resinextractable $\mathrm{P}$ that we measured as a consequence of prescribed burning are biologically meaningful. Increased P availability could affect postfire plant growth, particularly rooting (Marschner 1995) and the ability of legumes to fix N (Robson et al. 1981; Hingston et al. 1982; Crews 1993).

Water-soluble concentrations of $\mathrm{Na}^{+}$in surface soil layers often increase after fire (Nishita and Haug 1972). In a nearby study, in a shrub-dominated mesic riparian area, water-soluble $\mathrm{Na}^{+}$in the surface layer after a prescribed burn was more than double that of the nonburned control (Blank et al. 2003). Sodium is generally considered a beneficial nutrient, and certain plants do benefit from $\mathrm{Na}^{+}$additions (Marschner 1995), but we know almost nothing about the $\mathrm{Na}^{+}$requirements of plants in these environments.

\section{Overseeding with $B$. tectorum and Nutrient Availability}

For the Utah sites, overseeding with $B$. tectorum did not affect nutrient availability (Table 4). Overseeding with B. tectorum on the Nevada sites interacted with the prescribed burning treatment to affect nutrient availability (Fig. 3; Table 3). On the burned plots, availability of $\mathrm{Fe}, \mathrm{Mg}^{+2}$, and $\mathrm{Ca}^{+2}$ was significantly greater on overseeded plots relative to nonseeded areas. In addition, on unburned treatments, there was significantly less $\mathrm{Mg}$ availability on overseeded plots relative to nonseeded areas (trend was similar for $\mathrm{Fe}$ and $\mathrm{Ca}$ ). For the Nevada site, we reject null hypothesis 3 because seeding of $B$. tectorum affected the availabilities of $\mathrm{Fe}, \mathrm{Mg}^{+2}$, and $\mathrm{Ca}^{+2}$.

We were surprised that $B$. tectorum overseeding did not have an impact on soil nutrient availability of nitrogen and phosphorus. In unpublished greenhouse studies by the first author, resin capsules placed in the rooting zone of B. tectorum invariably had higher amounts of ortho-P relative to unplanted controls that were watered similarly. In addition, particular plant species differentially affect nutrient cycling processes, particularly nitrogen (Ehrenfeld 2003). The lack of a B. tectorum overseeding effect on macronutrients may be a consequence of relatively poor seedling recruitment. For Nevada, out of 648 seeds sown on the $0.75 \times 0.75 \mathrm{~m}$ plots, seedling densities of cheatgrass averaged, for crested wheatgrass and low, middle, and high sites, respectively, 13, 63, 58, and 13 from 2002 through 2005. Recruitment was even less for the Utah sites. Moreover, visual inspection of the overseeded plots indicated poor growth of individual plants. Nonetheless, for the Nevada sites, overseeding did increase the availability of Fe, $\mathrm{Mg}^{+2}$, and $\mathrm{Ca}^{+2}$ but only on the prescribed burned plots. Exudation of low molecular weight organic acids from $B$. tectorum roots could solubilize $\mathrm{Fe}, \mathrm{Ca}$, and $\mathrm{Mg}$ (Ström et al.
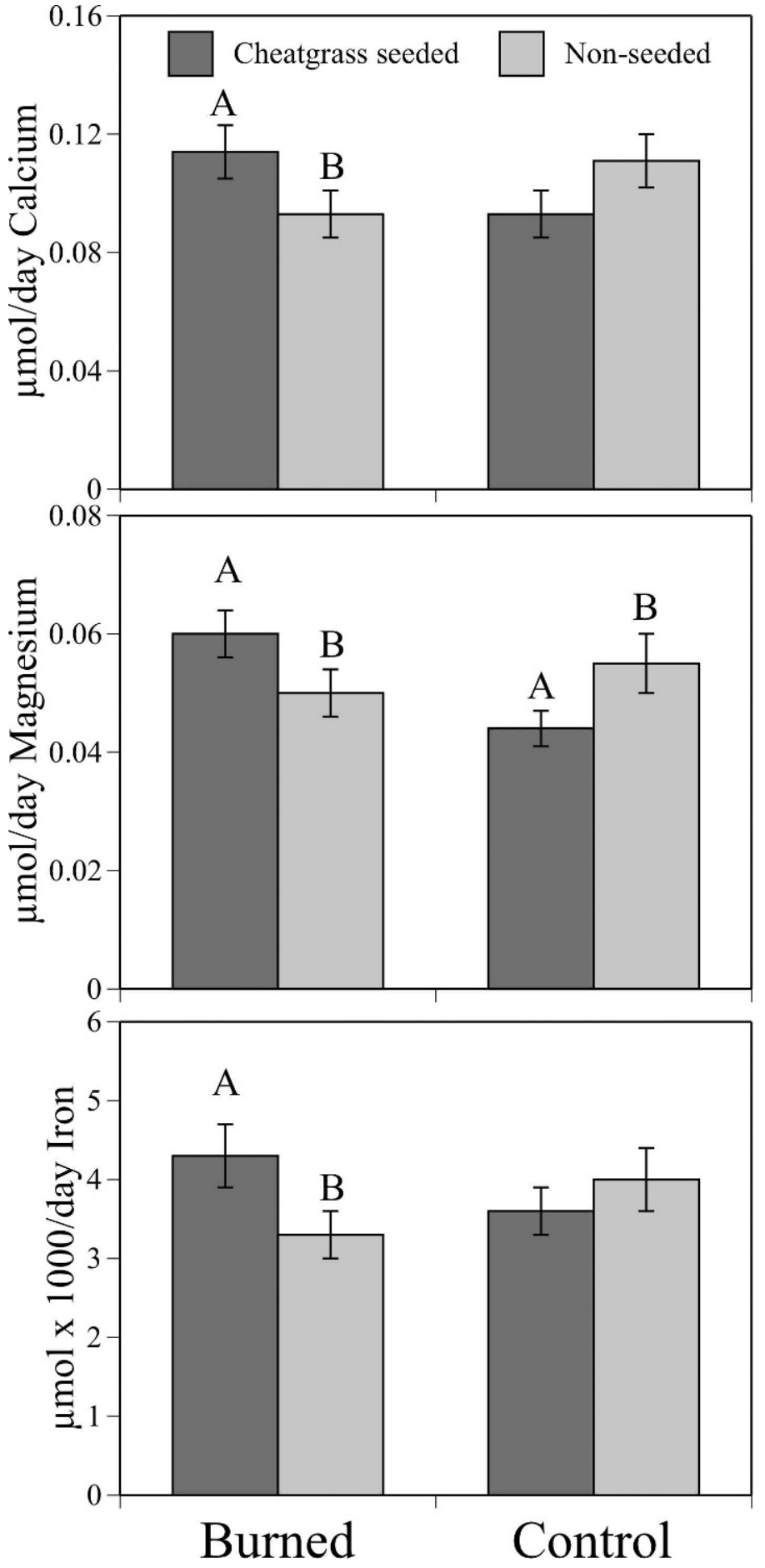

Figure 3. Mean resin availability of calcium, magnesium, and iron as affected by $B$. tectorum overseeding (Nevada only). Data are pooled over site, herbaceous removal treatment, and integration period. Bars are $1 \mathrm{SE}$. For each panel, letters above bars denote significant differences $(P<0.10)$.

1994). However, why those increases would occur only on prescribed burned soils is, at this time, unexplainable.

\section{Nutrient Availability and Season}

Nutrients available to resin capsules varied significantly depending on the integration period (Fig. 4; Tables 3 and 4). Indeed, the season of integration influenced the availability of 

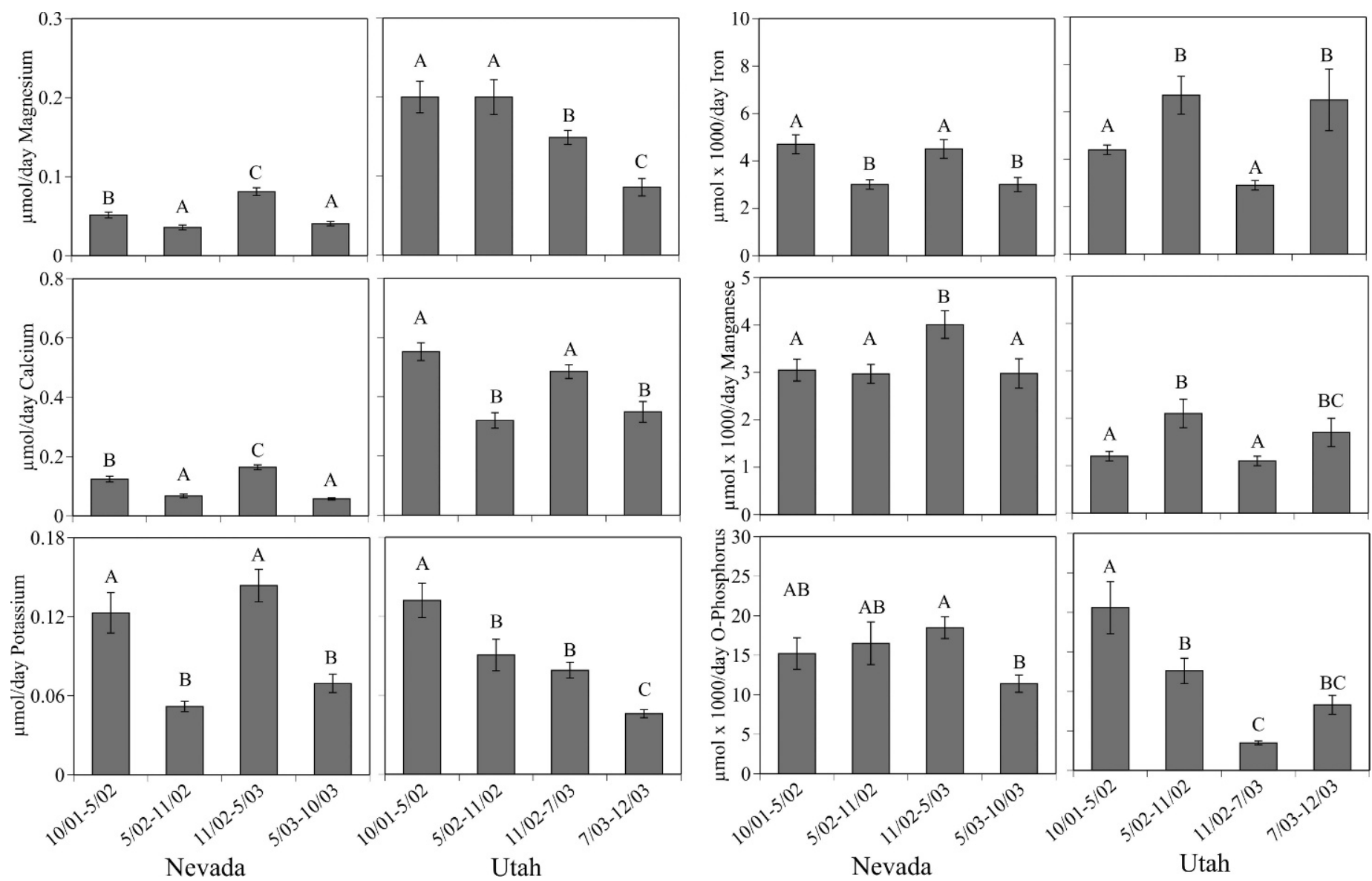

Figure 4. Mean resin availability of magnesium, calcium, potassium, iron, manganese, and ortho-phosphorus as affected by sampling period. Data are pooled over site, herbaceous removal, and burn and overseeding treatments. Bars are 1 SE. For each panel, letters above bars denote significant differences $(P<0.10)$.

more nutrients than any imposed treatment. For the Nevada sites, nutrient availability of $\mathrm{Mg}^{+2}, \mathrm{Ca}^{+2}, \mathrm{~K}^{+}$, and $\mathrm{Fe}$ was greatest during the fall-to-spring integration periods relative to the spring-to-fall integration periods. In contrast, for the Utah sites, only $\mathrm{Ca}^{+2}$ availability exhibited a similar seasonal relationship; indeed, availability of $\mathrm{Fe}$ and $\mathrm{Mn}$ showed the opposite relationship. Availability of $\mathrm{Mg}^{+2}$ and $\mathrm{K}^{+}$declined during each resin-integration period for the Utah sites. Ortho-P availability was statistically similar for the first 3 integration periods and was least during the last integration period for the Nevada sites and varied considerably among integration periods for the Utah sites. Nitrate availability was unaffected depending on integration period for the Utah sites and was greatest during the third integration period for the Nevada sites (see Fig. 2). These data support rejection of null hypothesis 4 and indicate that soil availabilities of many nutrients were affected by season of measurement.

Nutrient capture by resin capsules is largely controlled by diffusion; thus, explanation of differences in nutrient availability among seasons should consider those factors that affect diffusion: temperature, soil moisture content, concentration gradients, and soil physical factors, such as clay mineralogy and texture (Barber 2001). Ion diffusion rates generally increase with temperature, but soil water content is an overriding control on diffusion rates, and diffusion rates greatly increase with increasing soil water content (Schaff and Skogley 1982). Our study sites receive the majority of precipitation during the winter (Fig. 5); thus, one would expect, on a per-unit time basis, that nutrient availability, as gauged by resin capsule capture, would be highest during the winter. Indeed, for the Nevada sites, that model explains higher availability of $\mathrm{Mg}^{+2}$, $\mathrm{Ca}^{+2}, \mathrm{~K}^{+}$, and $\mathrm{Fe}$ during the fall-spring integration periods relative to the spring-fall periods. In Utah, $\mathrm{Ca}^{+2}$ availability is, like Nevada, greatest during the fall through spring integration periods. In contrast, $\mathrm{Fe}$ and $\mathrm{Mn}$ availability is greatest during the hotter and drier spring through fall integration period. We hypothesize that this pattern may be related to elevated microbial activity because that affects the contribution of organic acid and siderophores, which increase the availability of $\mathrm{Fe}$ and $\mathrm{Mn}$. This process cannot operate equally in the Utah and Nevada sites given the divergent seasonal patterns. Finally, availability of ortho- $\mathrm{P}, \mathrm{Mg}$, and $\mathrm{K}$ for the Utah sites declined over time. Because there appears no distinct relationship of availability with either temperature or precipitation patterns (Fig. 5), a possible explanation for that pattern eludes us.

The seasonal aspects of nutrient availability have ramifications to plant ecology. For many nutrients, especially for the Nevada sites, peak availability (fall through spring period) is out of phase with the plant growth. Plant species capable of 

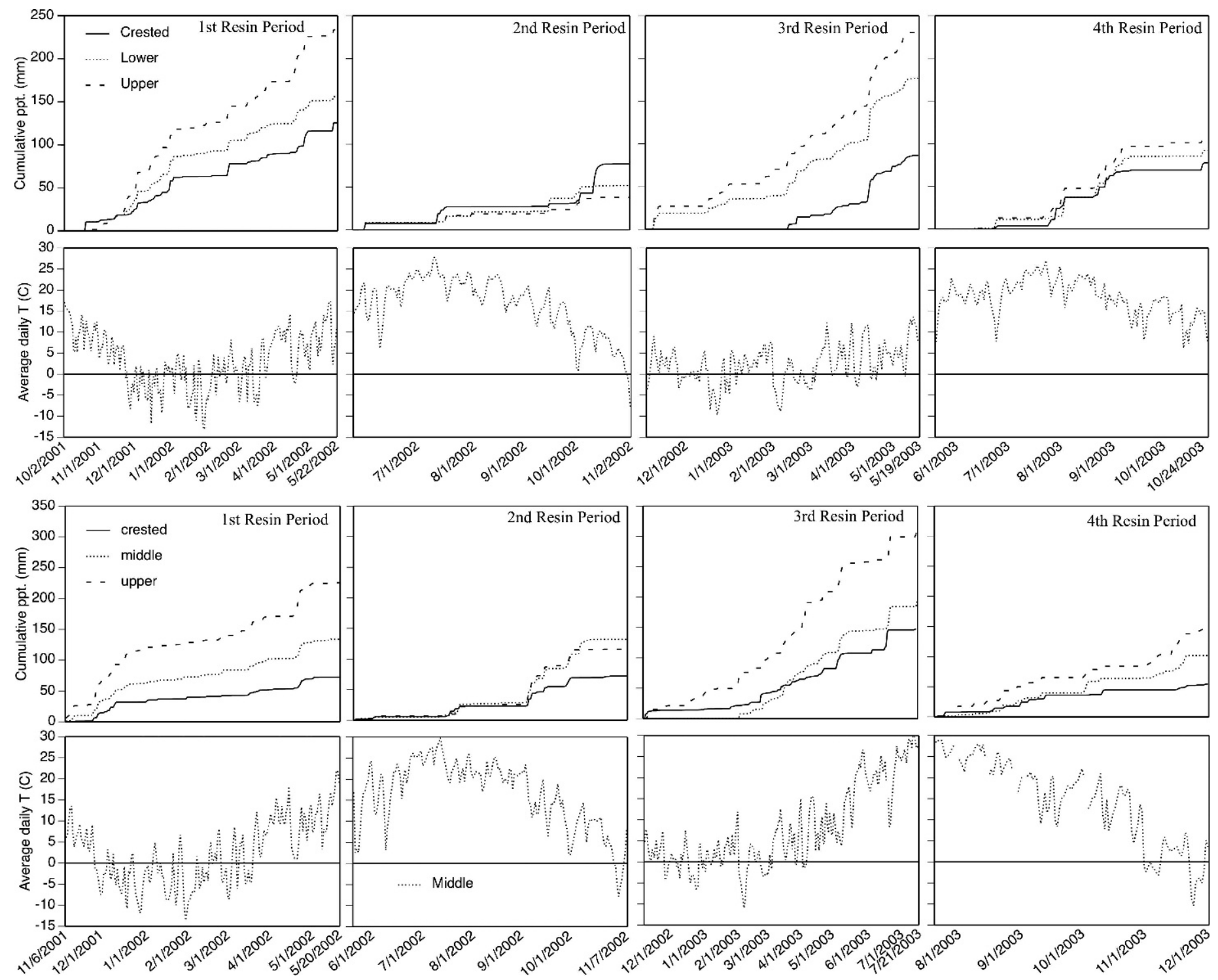

Figure 5. Cumulative precipitation and average air temperature, by resin sampling period, for the Nevada (top) and Utah sites (bottom). For clarity of presentation, only selected sites are shown. Unless otherwise noted, temperature data are for the lower sites.

active root uptake during those cold peak periods of nutrient availability may more readily acquire those nutrients and perhaps gain a competitive advantage over other species.

\section{Nutrient Availability and Site (Elevation)}

Each state had distinct patterns of nutrient availability by site (Fig. 6). For Nevada, ortho-P and K availability was greatest for the middle-elevation site and lowest for the crested wheatgrass and lower sites. Calcium availability was greatest for the lower sites and statistically similar among the other sites. Availability of $\mathrm{NO}_{3}^{-}$was least for the lowest site and statistically similar among the other sites. Manganese availability was least for the upper sites. No statistical differences occurred among Nevada sites for $\mathrm{Fe}, \mathrm{Na}$, and $\mathrm{Mg}$. Variation in nutrient availability by site was more pronounced for Utah, with a general trend of increasing nutrient availability with elevation for all nutrients measured (Fig. 6). These data support rejection of null hypothesis 5 and lead to the conclusion that soil availabilities of several nutrients are affected by elevationmoisture gradients.

As evoked in the discussion for season, soil water content is likely a major factor controlling site (elevation) differences in nutrient availability. Precipitation data during capsule sampling periods show that during the fall through spring integration periods, cumulative precipitation was greatest for the highelevation sites and least for the low-elevation sites (Fig. 5). This mechanism certainly has utility in explaining the increase in availability with elevation exhibited by many nutrients, especially for the Utah site; however, the lack of a distinct trend in availability with elevation for some nutrients suggests alternative processes control availability. For Nevada, the middle site often had the highest nutrient availability. That particular site was on a north-facing alluvial fan and received more shading than the other sites. Soil water availability at that site, however, was intermediate between the lower and upper elevational sites (Whittaker 2006). 

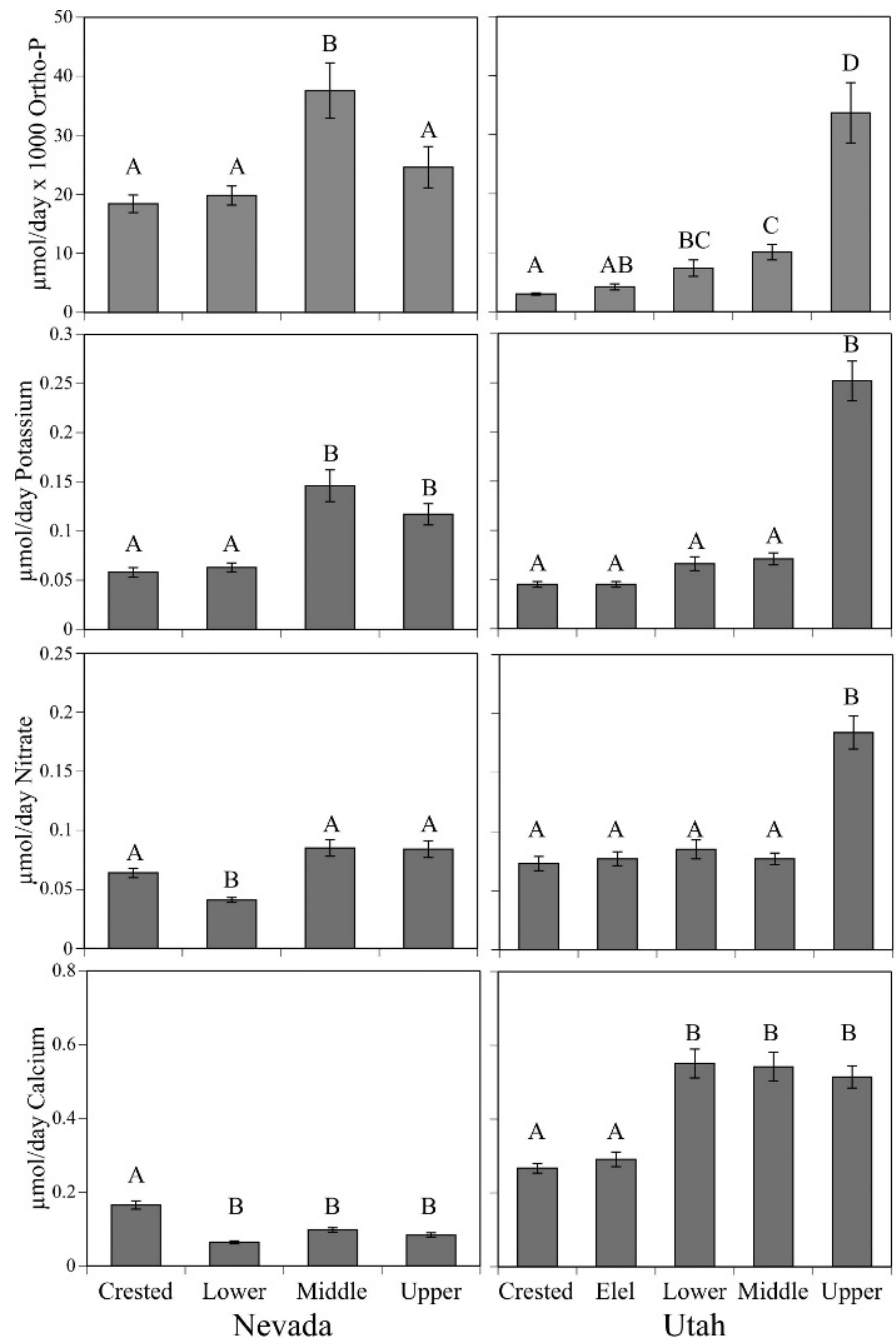
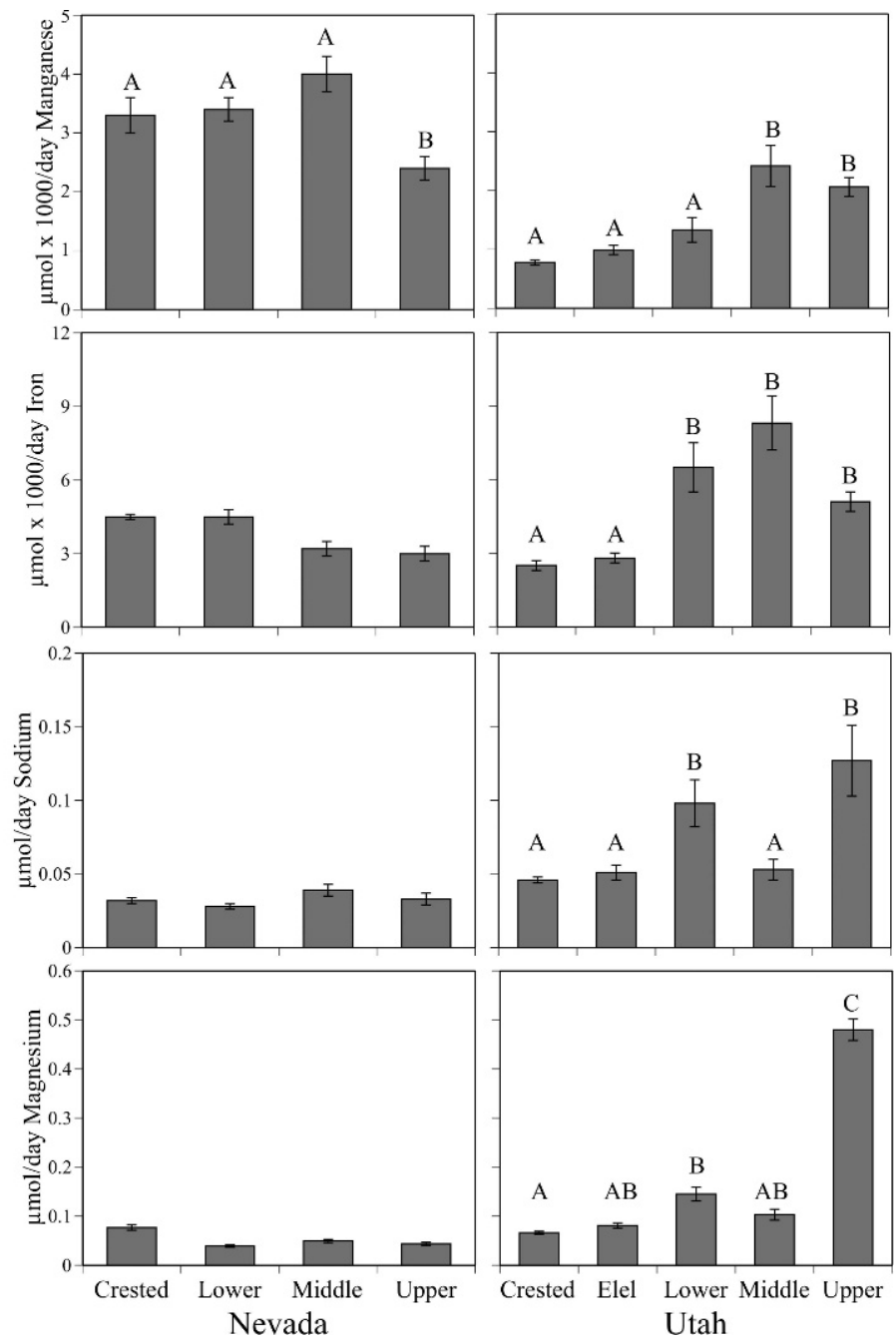

Figure 6. Mean resin availability of ortho-phosphorus, potassium, nitrate, calcium, manganese, iron, sodium, and magnesium as affected by site. Data are pooled over integration period, herbaceous removal, and burn and overseeding treatments. Bars are $1 \mathrm{SE}$. For each panel, letters above bars denote significant differences $(P<0.10)$.

\section{IMPLICATIONS}

This study is one of the first to employ resin-exchange capsules in a rangeland ecosystem to monitor soil nutrient availability. We believe that this technique provides a realistic integration of soil nutrient availability for comparison purposes. This technique was able to reproducibly record the availability of all the macro-, meso-, and micronutrients except $\mathrm{NH}_{4}^{+}$and $\mathrm{SO}_{4}^{-2}$ (high blanks) and $\mathrm{Co}, \mathrm{Mo}, \mathrm{Cu}$ (below instrumentdetection limits).

Our resin-derived data support the principle that disturbance, in its many manifestations, does influence soil nutrient availability (bioavailability). Herbaceous vegetation removal and prescribed fire increased the availability of $\mathrm{NO}_{3}^{-}$, which suggests that those disturbances potentially provide an opportunity for invasive weeds to proliferate. Increases in ortho-P availability after the prescribed burning treatment may have important consequences for rooting of newly establishing plants and for the ability of leguminous forbs to fix atmospheric $\mathrm{N}$. Increases in $\mathrm{K}$ availability after the prescribed fire treatment may influence the cold tolerance of newly establishing plants. We can offer no insight concerning a threshold of nutrient availability whence cheatgrass becomes invasive. Poor growth of overseeded cheatgrass suggests that resin nutrient availability did not exceed a threshold. Alternatively, other soil factors unrelated to nutrient availability may have suppressed growth of overseeded cheatgrass.

\section{ACKNOWLEDGMENTS}

The authors thank Ms Tye Morgan for field and laboratory assistance and Mr Dave Board for statistical analyses.

\section{LITERATURE CITED}

Abrams, M. M., and W. M. Jarrell. 1992. Bioavailability index for phosphorus using ion exchange resin impregnated membranes. Soil Science Society of America Journal 56:1532-1537.

Ågren, G. I., and E. Bosatta. 1996. Theoretical ecosystem ecology: Understanding element cycles. Cambridge, UK: Cambridge University Press. $250 \mathrm{p}$. 
BARBER, S. A. 2001. Soil nutrient bioavailability: A mechanistic approach. New York, NY: John Wiley and Sons. $432 \mathrm{p}$.

Bazzaz, F. A. 1996. Plants in changing environments-Linking physiological, population, and community ecology. Cambridge, UK: Cambridge University Press. $330 \mathrm{p}$.

BeLnaP, J., AND S. L. Phillips. 2001. Soil biota in an ungrazed grassland: response to annual grass (Bromus tectorum) invasion. Ecological Applications 11:1261-1275.

Binkley, D., J. Aber, J. Pastor, and K. Nadelhoffer. 1986. Nitrogen availability in some Wisconsin forests: comparisons of resin bags and on-site incubations. Biology and Fertility of Soils 2:77-82.

Blank, R. R., F. Allen, and J. A. Young. 1994. Extractable anions in soils following wildfire in a sagebrush-grass community. Soil Science Society of America Journal 58:564-570.

Blank, R. R., J. Chambers, and D. Zamudio. 2003. Prescribed burning of central Nevada degraded riparian ecosystems: effects on soil and vegetation. Journal of Range Management 56:388-396.

BowEN, G. D. 1991. Soil temperature, root growth, and plant function. In: Y. Waisel, A. Eshel, and U. Kafkafi [EDs.]. Plant roots: The hidden half. New York, NY: Marcel Dekker. p. 309-330.

Brooks, M. L. 1999. Habitat invasibility and dominance of alien annual plants in the western Mojave desert. Biological Invasions 1:325-337.

Brooks, P. D., M. W. Williams, And S. K. Schmidt. 1996. Microbial activity under alpine snowpacks, Niwot Ridge, Colorado. Biogeochemistry 32:93113.

BuRKE, I. C. 1989. Control of nitrogen mineralization in a sagebrush steppe landscape. Ecology 70:1115-1126.

Burke, M. J., And J. P. Grime. 1996. An experimental study of plant community invasibility. Ecology 77:776-790.

Chapin, F. S., III. 1980. The mineral nutrition of wild plants. Annual Review of Ecology and Systematics 11:233-260.

Crawley, M. J. 1987. What makes a community invasible? In: A. J. Gray, M. J. Crawley, and P. J. Edwards [EDS.]. Colonization, succession, and stability. London, UK: Blackwell Science. p. 429-453.

Crews, T. E. 1993. Phosphorus regulation of nitrogen fixation in a traditional Mexican agroecosystem. Biogeochemistry 21:141-166.

CuI, M., and M. M. Caldwell. 1997. A large ephemeral release of nitrogen upon wetting of soil and corresponding root responses in the field. Plant and Soil 191:291-299.

Davis, M. A., J. P. Grime, And K. Thompson. 2000. Fluctuating resources in plant communities: a general theory of invasibility. Journal of Ecology 88:528-534

Davis, M. A., and M. Pelsor. 2001. Experimental support for a resource-based mechanistic model of invasibility. Ecology Letters 4:421-428.

Davy, A. J., And K. TayLoR. 1974. Seasonal pattern of nitrogen availability in contrasting soils in the Chiltern Hills. Journal of Ecology 62:793-807.

DeBano, L. F., and C. E. ConRad. 1978. The effect of fire on nutrients in a chaparral ecosystem. Ecology 59:489-497.

DeBano, L. F., D. G. Neary, and P. F. Flollott. 1998. Fire's effects on ecosystems. New York, NY: John Wiley and Sons. 352 p.

Doescher, P. S., R. F. Miller, and A. H. Winward. 1984. Soil chemical patterns under eastern Oregon plant communities dominated by big sagebrush. Soil Science Society of America Journal 48:659-663.

Drohan, P. J., D. J. Merkler, and B. J. Buck. 2005. Suitability of the plant root simulator probe for use in the Mojave Desert. Soil Science Society of America Journal 69:1482-1491.

Duchaufour, P. 1977. Pedology. Translated by T. R. Paton. London, UK: George Allen \& Unwin. $448 p$

DudLeY, J. L., AND K. LAJTHA. 1994. The effects of prescribed burning on nutrient availability and primary production in sandplain grasslands. American Midland Naturalist 130:286-298.

Ehrenfeld, J. G. 2003. Effects of exotic plant invasion on soil nutrient cycling processes. Ecosystems 6:503-523.

Evans, R. D., R. Rimer, L. Sperry, and J. Belnap. 2001. Exotic plant invasion alters nitrogen dynamics in an arid grassland. Ecological Applications 11:1301-1310.
Farley, R. A., and A. H. Fitter. 1999. Temporal and spatial variation in soil resources in a deciduous woodland. Journal of Ecology 87:688-696.

GoldBERG, D. E. 1990. Components of resource competition in plant communities. In: J. B. Grace and D. Tilman [EDS.]. Perspectives on plant competition. San Diego, CA: Academic Press. p. 27-49.

Grime, J. P., J. C. CRick, and J. E. Rincon. 1986. The ecological significance of plasticity. In: D. H. Jennings and A. J. Trewars [EDS.]. Plasticity in plants. Cambridge, UK: Society of Experimental Biology. p. 5-29.

Grogan, P., and S. Jonasson. 2003. Controls on annual nitrogen cycling in the understory of a subarctic birch forest. Ecology 84:202-218.

Gross, K. L., K. S. Pregitzer, and A. J. Burton. 1995. Spatial variation in nitrogen availability in three successional plant communities. Journal of Ecology 83:357-368

Grover, J. P. 1997. Resource competition. London, UK: Chapman and Hall. 352 p.

Guo, D., P. Mou, R. H. Jones, and R. J. Mitchell. 2004. Spatio-temporal patterns of soil available nutrients following experimental disturbance in a pine forest. Oecologia 138:613-621.

Gurlevik, N., D. L. Kelting, and H. Lee Allen. 2004. Nitrogen mineralization following vegetation control and fertilization in a 14-year-old loblolly pine plantation. Soil Science Society of America Journal 68:272-281.

Herron, G. J., R. L. Sheley, B. D. Maxwell, and J. S. Jacobsen. 2001. Influence of nutrient availability on the interaction between Centaurea maculosa and Pseudoroegneria spicata. Ecological Restoration 9:326-331.

Hingston, F. J., N. Malajczuk, and T. S. Grove. 1982. Acetylene reduction $\left(\mathrm{N}_{2}\right.$ fixation) by Jarrah Forest legumes following fire and phosphate application. Journal of Applied Ecology 19:631-645.

HobBs, N. T., AND D. S. Schimel. 1983. Fire effects on nitrogen mineralization and fixations in mountain shrub and grassland communities. Journal of Range Management 37:402-405.

Jackson, R. B., J. Canadell, J. R. Ehleringer, H. A. Monney, O. E. Sala, and E. D. Schultze. 1996. A global analysis of root distributions for terrestrial biomes. Oecologia 108:389-411.

JansSeN, B. H. 1996. Nitrogen mineralization in relation to $\mathrm{C}: \mathrm{N}$ ratio and decomposability organic material. Plant and Soil 181:39-45.

Johnson, D. W., P. S. J. Verburg, and J. A. Arnone. 2005. Soil extraction, ion exchange resin, and ion exchange membrane measure of soil mineral nitrogen during incubation of a tallgrass prairie soil. Soil Science Society of America Journal 69:260-265.

Korfmacher, J. L., J. C. Chambers, R. J. Tausch, B. A. Roundy, S. E. Meyer, and S. KITCHEN. 2002. Technical note: a technique for conducting small-plot burn treatments. Journal of Range Management 56:251-254.

Larigauderie, A., and J. H. Richards. 1994. Root proliferation characteristics of seven perennial arid-land grasses in nutrient-enriched microsites. Oecologia 99:102-111.

LodHIL, M. A. K. 1981. Accelerated soil mineralization, nitrification, and revegetation of abandoned fields due to the removal of crop-soil phytotoxicity. Journal of Chemical Ecology 7:685-694.

Marschner, H. 1995. Mineral nutrition of higher plants. London, UK: Academic Press. 889 p.

McBride, M. B. 1994. Environmental chemistry of soils. New York, NY: Oxford Press. $416 p$

Misra, M. K., K. W. Ragland, and A. J. Baker. 1993. Wood ash composition as a function of furnace temperature. Biomass and Bioenergy 4:103-116.

Monaco, T. A., D. A. Johnson, J. M. Norton, T. A. Jones, K. J. Connors, J. B. Norton, and M. B. Redinbaugh. 2003. Contrasting responses of Intermountain West grasses to soil nitrogen. Journal of Range Management 56:282-290.

Neary, D. G., C. C. Klopatek, L. F. DeBano, and P. F. Ffolliot. 1999. Fire effects on belowground sustainability: a review and synthesis. Forest Ecology and Management 122:51-71.

NishitA, H., AND R. M. HAUG. 1972. Some physical and chemical characteristics of heated soils. Soil Science 113:422-430.

Pickett, S. T. A., AND P. S. White. 1985. The ecology of natural disturbance as patch dynamics. New York, NY: Academic Press. 472 p.

Pyne, S. J., P. L. Andres, and R. D. Laven. 1996. Introduction to wildland fire. 2nd ed. New York, NY: John Wiley and Sons. 682 p. 
Ralson, R. J. 1979. Modification of the soil environment by vegetation fires, with particular reference to nitrogen. Plant and Soil 51:73-108.

RAU, B. 2005. Soil physical, chemical and understory plant nutritional response to pinyon-juniper encroachment and prescribed fire in a central Nevada woodland [thesis]. Reno, NV: University of Nevada. $137 \mathrm{p}$.

Robson, A. D., G. W. O'Hara, And L. K. Аввотt. 1981. Involvement of phosphorus in nitrogen fixation by subterranean clover (Trifolium subterraneum L.). Australian Journal of Plant Physiology 8:427-436.

Saggar, S., M. J. Hedley, R. E. White, P. E. H. Greg, K. W. Perrott, and I. S. CoRnforth. 1992. Development and evaluation of an improved soil test for phosphorus, 2: comparison of the Olsen and mixed cation-anion exchange resin tests for predicting the yield of ryegrass grown in pots. Fertilizer Research 33:135-144.

SAS. 2001. SAS user's guide. Version 6.0. Cary, NC: SAS Institute Inc.

Schaff, B. E., and E. O. Skogley. 1982. Diffusion of potassium, calcium and magnesium in Bozeman silt loam as influenced by temperature and moisture. Soil Science Society of America Journal 46:521-524.

Searle, P. L. 1988. The determination of phosphate-extractable sulphate in soil with an anion-exchange membrane. Communications in Soil Science and Plant Analysis 19:1477-1493.

Sherrod, S. K., J. Belnap, and M. E. Miller. 2003. Comparison of ion-exchange resin counterions in the nutrient measurement of calcareous soils: implication for correlative studies of plant-soil relationships. Communications in Soil Science and Plant Analysis 34:1981-2003.

Stohlgren, T. J. 1999. The rich get richer: patterns of plant invasion in the United States. Frontiers in Ecology and the Environment 1:11-14.

Ström, L., T. Olsson, and G. Tyler. 1994. Differences between calcifuge and acidifuge plants in root exudation of low-molecular organic acids. Plant and Soil 167:239-245.
Stroup, W. W. 1989. Predictable function and prediction space in the mixed model procedure. In: Application of mixed models in agriculture and related disciplines. Baton Rouge, LA: Louisiana Agricultural Experiment Station. Southern Cooperative Series Bulletin 343. p. 39-48.

TILmAn, D. 1982. Resource competition and community structure. Princeton, NJ: Princeton University Press. 296 p.

Tisdale, S. L., And W. L. Nelson. 1975. Soil fertility and fertilizers. New York, NY: Macmillan Publishing. 694 p.

TuInIngA, A. R., AND J. DIGHTon. 2004. Changes in ectomycorrhizal communities and nutrient availability following prescribed burns in two upland pine-oak forests in the New Jersey pine barrens. Canadian Journal of Forest Research 34:1755-1765.

van RaiJ, B., J. A. Quaggio, and N. M. de Silva. 1986. Extraction of phosphorus, potassium, calcium and magnesium from soils by an ion exchange resin procedure. Communications in Soil Science and Plant Analysis 17:547-566.

Vitousek, P. M., L. R. Walker, L. D. Whiteaker, D. Mueller-Dombois, and P. A. Matson. 1987. Biological invasion by Myrica faya alters ecosystem development in Hawaii. Science 238:802-804.

WHITE, P. F. 1990. Soil and plant factors relating to the poor growth of Lupinus species on fine-textured, alkaline soils-a review. Australian Journal of Agricultural Research 41:871-890.

WHITTAKER, A. 2006. The effect of herbaceous species removal, fire, and cheatgrass (Bromus tectorum) on soil water availability [thesis]. Provo, UT: Brigham Young University. $33 p$.

Wright, H. A., And A. W. Balley. 2004. Fire ecology, United States and Canada. New York, NY: Wiley-Interscience. $528 \mathrm{p}$.

Yang, J. E., and E. O. Skogley. 1992. Diffusion kinetics of multinutrient accumulation by mixed-bed ion-exchange resin. Soil Science Society of America Journal 56:408-414. 